\title{
Lessons Learned from a Distance Course: "More Use Could Have Been Made of It"
}

\author{
Isabel Álvarez Cánovas ${ }^{1}$, Carles Dulsat Ortiz ${ }^{2, *}$ \\ ${ }^{1}$ Faculty of Education Sciences, Autonomous University of Barcelona, Spain \\ ${ }^{2}$ Department of Pedagogy and Didactics, Faculty of Education Sciences, University of A Coruña, Spain
}

Copyright $\mathrm{O} 2018$ by authors, all rights reserved. Authors agree that this article remains permanently open access under the terms of the Creative Commons Attribution License 4.0 International License

\begin{abstract}
This paper describes the on-line courses for sport technicians. It approaches them to show the virtues of this formative modality. In the Educational Spanish System, the sportive technician training is part of special teaching, and many of specialties are in transitional period. The final of this period concludes in the official recognition of the titles. It is, therefore, that it compares to post-compulsory studies, baccalaureate and vocational training, to check the evolution that has occurred in recent years. For this study, we have a data producing sample near to 100 students. They answered an ad-hoc questionnaire with two parts: one with quantitative data and the other with qualitative data. The main conclusions reached by the study are: the students have a very high degree of acceptance of the new technologies and a good opinion of the use of Moodle platform. These results are independents of the experience of distance learning. The majority of negative attitudes towards this course come from those students without experience in distance training. The problems are in the use that the teachers make of the platform because it hinders the flexibility of the course.
\end{abstract}

Keywords Distance Learning, Sport Training, Transitional Period

\section{Introduction}

In Spain, Skate Technicians are being trained by the Spanish Skating Federation and has been a standard bearer throughout the country at every level of each of its specialities. This is because of the heterogeneous distribution both of the practice of the different specialities and the number of people who participate in them [1]. This distribution entails certain difficulties when it comes to actually carrying out the courses in the different autonomous regions, with few of them being able to offer training close to the trainees' residence.

This coincides with the development and implementation of training plans for the specialities currently existing in the federation. The first proposal to be accepted by The National Sports Council was published in June 2012 [2] and in June 2015 [3] after certain modifications had been made. These training plans are at a transitional stage, so the qualifications obtained will become official as soon as the training plans are granted the status of Royal Ordinance, with ministerial recognition, and within the regulated training scheme. These plans envisage the possibility of the training being carried out on-line, on a semi-classroom basis, or entirely in a classroom, and of doing the whole course or focusing on specific areas.

On this basis, and in the light of the experiences of the 2008 to 2009 and the 2013 to 2014 on-line courses to qualify as national coaches in the different specialities, the Moodle platform is now being used as a tool in the teaching and learning process for interaction between teachers and students, and among the students themselves. The factors that have given rise to the use of this platform were several: it brings people from different parts of the country together $[4,5]$; it reduces the cost of the courses for the students [6, 7]; it makes teaching more democratic [8-10], in that the only potential obstacle is the availability of internet [11].

This training, generally little-known and seldom used but spreading rapidly at post-obligatory educational levels, could give rise to certain reservations on the students' part when enrolling on account of its markedly technological nature; it is with this in mind that we have prepared table 1, which shows the extent of the growth of such platforms in post-obligatory education: especially baccalaureates and educational cycles.

We can see that despite a decline in the total number of students at both educational levels, in each of the courses there has been a slight increase in the number of students in comparison with the previous academic year. With the exception of the academic year 2015-2016, when there was a percentage fall in the number of on-line students [12].

This is how this article aims to identify and describe the use of Moodle platform in the sports technician courses. 
Another objective of this study is to distinguish between the different sports specialities of the Federation in the use of the platform. In addition, it aims to propose solutions adapted to the specific characteristics of the sport specialities, and to involve participants (teachers, students and administration) in the use of the new technologies in general and the Moodle in particular as a tool for exchange and interaction among them.

\section{Methodology}

The methodology applied was mixed methods, with the differences that the students in the four specialities in the use of the online platform being highlighted. An ad-hoc questionnaire consisting of two parts was set up: a) with 9 items relating to quantitative personal characteristics and to their experience of online training; and b) a qualitative part, 4 items relating to the change to online training with the use of new technologies.
The sample of this study was initial level 1 courses for sports technicians, under the distance training model, throughout Spain. These courses are offered for four sports specialities: roller-blade hockey, roller-skate hockey, speed hockey and artistic hockey. Currently there are a total of eleven sports specialities under the umbrella of the Federation, but these four are the only ones that have continued, since 2012, with the same training plans that were approved by the National Sport Council. This first academic year chosen as a context for the present study has a total of 213 students in three locations, of which 164 passed. However, the final sample was 90 .

The use of the Surveymonkey digital platform for the collection of online information contributed by the students is also used for the exclusively descriptive quantitative part. The analysis becomes more focused when it concerns qualitative methodology, with the use of the Nvivo software for the open answer questions on the questionnaire.

Table 1. Student data for the on-line model in post-obligatory education (Based on data provided by the Ministry of Education, Sport and Culture)

\begin{tabular}{|c|c|c|c|c|c|}
\hline \multirow{2}{*}{ Course } & Teaching & Total & $\begin{array}{c}\text { Percentage of } \\
\text { on-line students }\end{array}$ & $\begin{array}{c}\text { Variation with } \\
\text { respect to the } \\
\text { previous } \\
\text { course }\end{array}$ & $\begin{array}{c}\text { Percentage of on-line } \\
\text { students by gender }\end{array}$ \\
\hline \multirow{2}{*}{$2011-2012$} & Baccalaureate & 684697 & $7,06 \%$ & $5,70 \%$ & $\begin{array}{c}50 \% \text { male } \\
50 \% \text { female }\end{array}$ \\
\cline { 2 - 6 } & Vocational training & 610860 & $4,63 \%$ & $16,60 \%$ & $\begin{array}{c}31 \% \text { male } \\
69 \% \text { female }\end{array}$ \\
\hline \multirow{2}{*}{$2012-2013$} & Baccalaureate & 697605 & $8,67 \%$ & $9,2 \%$ & $\begin{array}{c}50.8 \% \text { male } \\
49.2 \% \text { female }\end{array}$ \\
\cline { 2 - 6 } & Vocational training & 639887 & $6,03 \%$ & $15,7 \%$ & $\begin{array}{c}33 \% \text { male } \\
67 \% \text { female }\end{array}$ \\
\hline \multirow{2}{*}{$2013-2014$} & Baccalaureate & 701006 & $8,77 \%$ & $7,0 \%$ & $\begin{array}{c}50.1 \% \text { male } \\
49.9 \% \text { female }\end{array}$ \\
\cline { 2 - 6 } & Vocational training & 697408 & 7.45 & $16,6 \%$ & $\begin{array}{c}34.7 \% \text { male } \\
65.3 \% \text { female }\end{array}$ \\
\hline \multirow{2}{*}{$2014-2015$} & Baccalaureate & 705231 & $7,97 \%$ & $1,4 \%$ & $\begin{array}{c}51.2 \% \text { male } \\
48.8 \% \text { female }\end{array}$ \\
\cline { 2 - 6 } & Vocational training & 793034 & $7,81 \%$ & $14,0 \%$ & $\begin{array}{c}37.1 \% \text { male } \\
62.9 \% \text { female }\end{array}$ \\
\hline \multirow{2}{*}{$2015-2016$} & Baccalaureate & 697699 & $7,51 \%$ & $-0,9 \%$ & $\begin{array}{c}50.9 \% \text { male } \\
49.1 \% \text { female }\end{array}$ \\
\cline { 2 - 6 } & Vocational training & 784540 & $7,38 \%$ & $3,1 \%$ & $\begin{array}{c}38.9 \% \text { male } \\
61.1 \% \text { female }\end{array}$ \\
\hline \multirow{2}{*}{$2016-2017$} & Baccalaureate & 707033 & $7,44 \%$ & $1,8 \%$ & $\begin{array}{c}50.7 \% \text { male } \\
49.3 \% \text { female }\end{array}$ \\
\hline
\end{tabular}


Table 2. Sample percentage

\begin{tabular}{|c|c|c|c|c|c|}
\hline & Students & $\begin{array}{c}\% \\
\text { course }\end{array}$ & $\begin{array}{c}\% \text { of } \\
\text { the } \\
\text { student } \\
\text { body }\end{array}$ & sample & $\begin{array}{c}\% \\
\text { sample }\end{array}$ \\
\hline $\begin{array}{c}\text { Roller-skate } \\
\text { Hockey } \\
\text { (RSH) }\end{array}$ & 32 & $19.51 \%$ & $40.63 \%$ & 13 & $14.44 \%$ \\
\hline $\begin{array}{c}\text { Roller-blade } \\
\text { Hockey } \\
\text { (RBH) }\end{array}$ & 17 & $10.37 \%$ & $70.59 \%$ & 12 & $13.33 \%$ \\
\hline $\begin{array}{c}\text { Speed } \\
\text { Skating } \\
\text { (SS) }\end{array}$ & 40 & $24.39 \%$ & $67.5 \%$ & 27 & $30.00 \%$ \\
\hline $\begin{array}{c}\text { Artistic } \\
\text { Skating } \\
\text { (AS) }\end{array}$ & 75 & $45.73 \%$ & $50.67 \%$ & 38 & $42,22 \%$ \\
\hline Total & 164 & $100 \%$ & 90 & \\
\hline
\end{tabular}

Table 3. Distance Training and Degree of Acceptance for each of the Specialties.

\begin{tabular}{|c|c|c|c|}
\hline Speciality & Sample & $\begin{array}{c}\% \text { Distance } \\
\text { Training } \\
\text { depending on } \\
\text { speciality }\end{array}$ & $\begin{array}{c}\text { Degree of } \\
\text { acceptance }\end{array}$ \\
\hline $\begin{array}{c}\text { Roller-skate } \\
\text { Hockey (RSH) }\end{array}$ & 13 & 53.85 & 3,1 \\
\hline $\begin{array}{c}\text { Roller-blade } \\
\text { Hockey (RBH) }\end{array}$ & 12 & 41.67 & 2,8 \\
\hline $\begin{array}{c}\text { Speed Skating } \\
\text { (SS) }\end{array}$ & 27 & 62.96 & 1,96 \\
\hline $\begin{array}{c}\text { Artistic Skating } \\
\text { (AS) }\end{array}$ & 38 & 47.37 & 2,6 \\
\hline total & 90 & 52.22 & 2,37 \\
\hline
\end{tabular}

\section{Analysis}

\subsection{Quantitative Analysis}

The data requested in this section of the questionnaire are: age, sex, sports speciality for which they have enrolled, the autonomous region where they live, the level of acceptance of new technologies, experience of online training, the platform used in other courses, their role in the courses they have participated in and the qualification obtained from previous online courses. From the quantitative results obtained we would especially like to highlight the data presented in table 3. Other elements that should be taken into account in this quantitative analysis include the participants' experience of distance learning, and the degree of acceptance of the new technologies that the students have access to; this quantitative item follows a numerical descriptive scale of 1 to 10 , where 1 is the maximum and 10 the minimum degree of acceptance.

A little more than half of the generative sample had experience distance training, with speed training being the speciality with the largest number of students who had done some form of distance training. As regards the degree of acceptance, it is very high, close to 1 , the average value for the students who answered the question the questionnaire being 2.37. It is the speed skating students who show the greatest degree of acceptance of new technologies, whereas the roller hockey students show the lowest degree of acceptance of new technologies.

\subsection{Qualitative Analysis}

The analysis of the answers is separated and the four items that relate to the new technologies and the platform:

\section{In your opinion, the use of the platform has been?}

The students of the speed skating speciality (only those with experience of Distance Training -from now on DT) are the ones that give negative opinions on the use of the platform. In the case of both groups, it is worth highlighting the fact that the use of the platform improves as time passes; rather than inexperience, it is a question of the willingness with which the teachers situate the elements and documents, and the way in which the federation manages the platform's space. In both groups of Artistic Skating students point out that the more they use the platform the better they understand it and the better their perception of it becomes. They attribute the problems associated with it to the attitude of the teachers, and to minimal interaction with the students through it, as they hardly ever visit the forums or reply to the email messages the students send them.

There are other comments relating to the good use of the platform than negative comments; even the initial problems were solved, which meant that the platform was easier to use. Students attribute misuse to the teachers, due to their instructions being too rigid, or because they never enter the forums that they themselves have set up. We detected differences in the experience of DT on the part of the roller-blade hockey students, whereby not having enough experience results in it being difficult to use the platform. In general, both groups comment on the difficulties at the beginning of the course, which, as they were solved, led to a more efficient use of the platform. It is also evident in the use of the platform that most of the problems arise due to the inadequate use that the teachers make of it, and because the way in which teachers manage the platform allows for little flexibility.

\section{What types of documents are most frequently used? Which do you think could have been used more?}

Both groups (with (without) experience in DT) coincide in making use of PDFs for the contents, and in the fact that these PDFs could be filled in in conjunction with accompanying videos to guide the user. Moreover, in both groups there are answers which claim that everything has been used. While for the students with experience in DT it is necessary to add PowerPoint slides to complement the contents, and to make greater use of internet links giving further explanation. In the no-experience group, there were 
requests to improve the explanations of the contents, and the use of the forums and message-sending facility. Both groups coincide in referring to the use of PDFs and written documents in general as the most widely used, and in saying that they would like to have had explanatory videos to provide examples of the theoretical contents. The students with DT experience add that there could have been videoconferences and that the bibliography provided by some teachers also helped them, so they would like all the teachers to provide such bibliographies. It is also worth adding, in relation to this group, that they would like there to be more use of everything that is available on internet.

For the Roller Hockey speciality, the opinion was expressed, both by those with and those without experience of DT, that it was necessary to provide more video demonstrations to accompany the theoretical content. Those with experience of DT added that videoconferences could also be used. It also emerged that PDF contents and questionnaires generated by the platform were the most frequently used facilities. It should also be pointed out that students with DT experience think that "more use could have been be made of it", (Student, 66) but without specifying what he or she is referring to. The students of the Roller-blade Hockey with DT experience would like there to be more discussion of topics and more use of the forums, whereas those without DT experience expressed a desire for more PowerPoints to summarize the content as a means of supporting their own notes. Both groups of students feel that what is lacking in the course is a more extensive use of demonstration videos to complement the explanatory notes provided, which in both cases take the form of PDFs or written text in general, or questionnaires. While students with experience request more bibliographies, some of the replies also suggest that it is fine as it is, but comments of this kind do not tend to be made by students without experience.

\section{What is your opinion of the platform?}

Speed Skating students with no DT experience make no negative comments about the platform, and two thirds of them state that it is good and very useful. Half of the students with DT experience express a similar opinion. About $20 \%$ of the students in both groups, depending on whether or not they have DT experience, referred to the difficulty they experience in using the platform at the beginning and state that it became easier over time. A quarter of the students with DT experience make negative comments about the platform, saying that it is complicated and chaotic. A small number of students with DT experience attribute the problems with the platform to the teachers, rather than to the platform itself.

While a quarter of the replies from Artistic Skating students with DT experience consider the platform to be good, in the case of students without DT experience the proportion is a third of the replies. In both cases references are made to the initial difficulties in using the platform which are gradually overcome with practice, with comments such as: "at the start it's all a bit complicated, but as you get used to it and see how it works, it's very good. The truth is that I'm very satisfied" (Student, 129). Both groups also point out that there is room for improvement. Whereas fewer than $10 \%$ of the students with experience consider the use of the platform to be complicated and unsatisfactory, in the case of students with no DT experience as many as a third of them express this view. It is the group made up of students with no experience that offers possible solutions, such as increasing the size of the font, and making navigation within the platform easier. Both groups express negative opinions, but with reference to the responsibility of the teachers rather than to the platform itself, such as the deadlines for the submission of assignments, insufficient use of the forums, or the questionnaires not being corrected. Several issues do have to do with the platform, however, such as difficulty in finding the marks that have been given for the different tasks or questionnaires.

For a third of the Roller Hockey students without DT experience, and for half of those with experience, the platform is good. A third of the students without DT experience and the same proportion of those with experience express the view that there is room for improvement. It is especially in the group of students with DT experience that we find replies relating to the initial difficulty of access to the platform, while a third of the students with no DT experience think it is very complicated attribute this problem to teacher-related factors. For Roller-blade Hockey students without DT experience the platform was difficult to use at the beginning, but the majority of them consider it to be good. Only one in four of the replies referred to its complexity: "I find it very difficult to do things well using this platform" (Student, 32). A third of the replies from students with DT experience express the view that the platform is good, while according to another third of them, there is room for improvement. A small number of students say that they find the platform complicated or difficult to use, mainly because communication with the teacher is slow, but also because the spaces and font sizes on the platform itself are so small.

\section{What is your opinion of how the platform Works and how it is managed?}

Three quarters of the Speed Skating students with no experience of DT consider the performance and management of the platform to be good and very effectively dealt with; $60 \%$ of the replies from students with DT experience express the opinion that the platform is well managed and works well. While $25 \%$ of the students with no DT experience consider the platform to be complicated, this percentage value drops to $15 \%$ in the case of students with experience. The former group says nothing about why it is complicated, while the group of students with experience refers to the need to improve the 
information uploaded on the platform, or the means whereby this information can be visualised; they also mention improvements that could be made to the use of blogs and forums. It is in the group with DT experience that we find replies that relate to the initial difficult in using the platform: "despite a few teething problems at the beginning, the platform is well-managed" (Student, 94). In addition, some replies in this group draw attention to the fact that some material is added as the course proceeds which is not available at the beginning. Finally, it is worth mentioning the following reply: "I can't compare the platform with other platforms" (Student, 89) within the group of students with no experience.

A third of the students with DT experience within the Artistic Skating group consider there it be room for improvement in the performance and management of the platform. This opinion is reflected in a quarter of the replies in the case of students with no DT experience. Fewer than $10 \%$ of the replies from students with DT experience express the view that the management and performance are inadequate because of the platform being complicated to use, while more than $15 \%$ of the answers from students with no DT experience suggest that the performance and management of the platform are very poor. Half of the replies from students with DT experience reflect a positive evaluation of both the performance and the management of the platform. This is also the view expressed by $40 \%$ of the students with no DT experience, mainly thanks to the good communication that is established with the teachers. As regards the remaining answers, less than $10 \%$ in the case of students with DT experience and $15 \%$ of those with no experience, while they express neither a negative nor a positive opinion in this regard, they do highlight certain aspects which are not working well, all of which relate to the teachers' tasks, such as the failure to correct assignments, not being present in the forums, or difficulty in visualising the PDFs. Take this comment to sum up this point: "It gives the impression of being a trial platform, and that this is the first course it's being used in." (Students, 62).

In both groups, depending on whether or not the students in the roller skate Hockey speciality have DT experience, a third of the replies refer to the performance and management of the platform as being in need of improvement, because the more days' practice they get, the better the platform works and the fewer mistakes are made, whereas half of the students with DT experience, two thirds of the students with no experience express the view that the platform works well. As regards the rest of the student body in Roller-skate Hockey, with DT experience, they consider the management of the platform to be poor, in that the documents do not load properly. Students in the Roller-blade Hockey speciality without DT experience fall into two categories: three quarters of their answers reflect a positive view of the performance and management of the platform, and the remaining quarter express the view that it is complicated: "very confusing, especially as far as the submission dates are concerned" (Students, 32). The Roller-blade Hockey students with DT experience present a broader range of answers, with $20 \%$ saying that they consider the management and performance of the platform to be good. Almost half the answers are negative, pointing out errors and problems relating to the dates when the course begins or technical issues, such as the fact that the links do not work properly. For another $20 \%$, the fact that the links fail is not mentioned as a negative point, as their answers express a positive view, such as the following one for example: "it has worked well for me every time I have connected, except for the links which don't work or don't appear as links" (Student, 86) Another nearly $20 \%$ of the students with DT experience are optimistic about the platform, and feel that the participants are not taking full advantage of the performance and management of the platform.

\section{Discussion}

Opinions about Moodle vary greatly depending on both level of DT experience and speciality. It is students in Speed Skating without DT experience who express the most positive opinion about the platform in all their answers. They are followed by the group of students in Roller-blade Hockey without experience, $75 \%$ of whose answers expressed a positive opinion. In the case of the Speed Skating and roller-skate Hockey students, both with DT experience, half of their answers concerning the platform expressed a positive opinion. One third of the Artistic Skating students and Roller-skate Hockey students without DT experience, and Roller-blade Hockey with DT experience, gave positive replies. Finally, $25 \%$ of the answers from students in the Artistic Skating speciality with DT experience were positive. These positive comments are aligned with the fact that the platform, in other words, Moodle as seen as an environment [13-17].

It should be pointed out that most of the replies that are negative, across the specialities, and irrespective of degree of DT experience, coincide in reflecting a positive evolution as students make more and more use of the platform, with most of the problems relating to the initial stages. They also concur across the range of specialities, and irrespective of DT experience, that part of the responsibility for the platform not working well lies with the teachers. These negative elements could be analyzed by seeing Moodle as a pedagogical tool $[18,19]$.

\section{Conclusions}

It can be concluded from the point of view of quantitative analysis, the degree of acceptance of the new technologies is indeed very high; from the point of view of 
qualitative analysis, the good general opinion is complemented by references to the use of the platform in particular, and to that of new technologies in general.

These results are independent of previous distance training experience and of the sports speciality of the student. Common to all the students across the range of specialities, regardless of their level of experience of DT, is the fact that their perception of the platform improves the more they use it. The problems generally have to do with the way it is managed by the teachers, as this often hampers the flexibility that this model should offer. The students who deviate from this generally positive perception are those without DT experience in the Roller-blade Hockey speciality, and students with DT experience in the Speed Skating speciality, the latter being the ones whose evaluation is most negative.

\section{REFERENCES}

[1] C. Dulsat. Les Resistències en la Formació a Distància dels Tècnics Esportius de la R.F.E.P. Ph. D. Thesis. Universitat Autònoma de Barcelona, 2015. http://hdl.handle.net/10803/ 326462 .

[2] M.E.C. Resolución de 26 de junio de 2012, de la Presidencia del Consejo Superior de Deportes, por la que se publica los planes formativos de las especialidades de hockey sobre patines, patinaje de velocidad, patinaje artístico y danza y hockey sobre patines en línea, pertenecientes a la modalidad deportiva de patinaje. Madrid, Boletín oficial del Estado, 2012. Available: http://www.boe.es/boe/dias/2012/07/26/pdfs/BOE-A-2012 -10054.pdf

[3] M.E.C. Resolución de 3 de junio de 2015, de la Presidencia del Consejo Superior de Deportes, por la que se publica los planes formativos de las especialidades de hockey sobre patines, patinaje de velocidad, patinaje artístico y danza y hockey sobre patines en línea, pertenecientes a la modalidad deportiva de patinaje. Madrid, Boletín oficial del Estado, 2015. Available: http://www.csd.gob.es/csd/estaticos/ens-deportivas/normat iva/RES\%203\%20JUNIO\%202015.\%20PF\%20PATINAJ E.pdf

[4] C. A. Gómez Londoño, G. A. Cárdenas. Distancia sin distancia. El oxímoron como lugar de encuentro de lo humano. Una mirada a la modalidad de educación a distancia desde la didáctica no parametral, Revista de Educación, Vol 40, No 2, pp 1-11, 2016. http://dx.doi.org/10.15517/revedu.v40i2.19488

[5] J. C. Guerrero. La educación virtual como factor de desarrollo competitivo. El caso de UDGvirtual, Red Internacional de Investigadores en Competitividad, Vol 2, No 1, pp 1-17, 2008.

[6] N. Cantora, A. Pantoja. La transformación de centros educatives en comunidades de aprendizaje (CdA) en laprovincia de Jaén, Profesorado. Revista de currículum y formación del profesorado, Vol 20, No 3, pp 715-749, 2016. Available: http://digibug.ugr.es/bitstream/10481/44633/1/rev203col13 .pdf

[7] Y. A. Opazo, A. E. M. Jaramillo, E. O. Marileo. Videos tutoriales: una alternativa de estudio para alumnos; nivel de autoaprendizaje y motivaciones. Revista Internacional de Educación y Aprendizaje, Vol 5, No 1, 2017. Available: $\mathrm{http}$ ://journals.epistemopolis.org/index.php/educacion/artic le/view/1391

[8] C. Chou, R. López Fernández, C. Sánchez Gálvez. Diseño metodológico para la implementación de los cursos a distancia en la Universidad Metropolitana. Universidad y Sociedad, Vol 9, No 1, pp 211-217, 2017. Available: https://rus.ucf.edu.cu/index.php/rus/article/view/528/pdf

[9] D. Davis, M. E. Palomeque, P. E. Crespo. La utilización de las tecnologías de la información y la comunicación como recurso didáctico en la educación superior. Didasc@lia: Didáctica y Educación., Vol VII, No 4, pp 259-272, 2016. Available:http://runachayecuador.com/refcale/index.php/di dascalia/article/view/1508/854

[10] F. J. López Benavides, M. C. Fuentes. Características del aprendizaje en los sistemas de educación abierta y a distancia. Tlatemoani. Revista Académica de Investigación, Vol 23, pp 26-33, 2016. Available: http://www.eumed.net/r ev/tlatemoani/23/educacion.pdf

[11] M. C. Chávez, J. Bojórquez. Nuevas tecnologías, nuevos valores y su impacto en la relación docente-alumno en el nivel medio superior. Atlante, Cuadernos de Educación y Desarrollo, pp 1-10, 2013. Available http://atlante.eumed.n et/wp-content/uploads/docente-alumno.pdf

[12] C. García Marcos, J. Cabero. Evolución y estado actual del e-learning en la Formación Profesional Española. RIED. Revista Iberoamericana de Educación a Distancia, Vol 19 , No 2, pp 167-191, 2016. http://dx.doi.org/10.5944/ried.19. 2.15800

[13] A. L. Arcienaga, M. A. Chávez, A. Iriarte, A. C. Ramírez. El potencial didáctico y la pertinencia tecnológica como factores para la elección de una plataforma de aprendizaje de un entorno virtual. Revista EDUCATECONCIENCIA, Vol. 12, No 13, pp 104-121, 2016. Available: http://www.tecnocientifica.com.mx/educateconciencia/ind ex.php/revistaeducate/article/view/240/220

[14] E. Dreizzen, A. Zangara, N. Alonso. Proceso de implementación del nuevo entorno virtual de enseñanza y aprendizaje Moodle de la Facultad de Ciencias Médicas dela UNLP. Planificación y temes críticos. Revista Iberoamericana de Educación en Tecnología y Tecnología en Educación, Vol 17, pp 52-57, 2016. Available: http://www.sedici.unlp.edu.ar/handle/10915/54201

[15] J. L. Maza, F. Tusa. Utilización del Moodle como un entorno personal de aprendizaje en contexto de educación superior: una revisión de literatura. Cumbres. Revista científica. 1 (2), 22-27, 2015. Available: http://www.invest igacion.utmachala.edu.ec/revistas/index.php/Cumbres/artic le/view/21/22

[16] R. Murrieta. Entornos virtuales de aprendizaje en educación superior: una experiencia con el uso del Moodle. Investigación Educativa en Educación, Vol 1, pp 1262-1265, 2016. Available: http://www.proceedings.ciaiq .org/index.php/ciaiq2016/article/view/727/714 
[17] J. Onrubia. Aprender y enseñar en entornos virtuales: actividad conjunta, ayuda pedagógica y construcción del conocimiento. Revista de Educación a Distancia, Vol 50, 2016. http://dx.doi.org/10.6018/red/50/3

[18] R. K. Kampa, P. Kaushik. Changing Paradigm: Enhancing LIS Education using Moodle Open Source Software: A Study. International Research: Journal of Library and Information Science, Vol 6, No 3, pp 438-447, 2016. Available
http://www.irjlis.com/wp-content/uploads/2016/11/7-IR-3

64-63.pdf

[19] A. J. Moreno. Moodle como herramienta educativa en el proceso de enseñanza-aprendizaje del alumnado de Formación Profesional Básica de la Ciudad Autónoma de Ceuta. Ph. D. Thesis Universidad Nacional de Educación a Distancia, 2016.https://creativecommons.org/licenses/by-n c-nd/4.0 